\title{
Comparative copro-diagnosis of Echinococcus multilocularis in experimentally infected foxes
}

\author{
Al-Sabi, M N S ; Kapel, C M O ; Deplazes, P ; Mathis, A
}

\begin{abstract}
Faecal samples from 15 foxes experimentally infected with Echinococcus multilocularis were examined until 90 days post-infection (dpi) by microscopical identification of eggs isolated by flotation/sieving, by coproantigen-enzyme-linked immunosorbent assay (cELISA), by polymerase chain reaction (PCR) on DNA, respectively, isolated directly from the faecal samples (copro-DNA PCR) and from the eggs obtained by the flotation/sieving procedure (egg-DNA PCR). Based on egg counts, three periods of the infection were defined: pre-patent (2-29 dpi), high patent (30-70 dpi) and low patent periods (71-90 dpi). Whereas all methods were highly sensitive with samples from the high patent period, cELISA was the most sensitive to detect pre-patent infections (63\%). Samples from the low patent infections were positive in $77 \%$ by microscopy and in $80 \%$ by egg-DNA PCR, being significantly more sensitive than cELISA and copro-DNA PCR. The isolation of eggs from the faecal material proved to be more sensitive by the flotation/sieving procedure as compared to the classical concentration McMaster technique.
\end{abstract}

DOI: https://doi.org/10.1007/s00436-007-0537-4

Posted at the Zurich Open Repository and Archive, University of Zurich

ZORA URL: https://doi.org/10.5167/uzh-18601

Journal Article

Published Version

Originally published at:

Al-Sabi, M N S; Kapel, C M O; Deplazes, P; Mathis, A (2007). Comparative copro-diagnosis of Echinococcus multilocularis in experimentally infected foxes. Parasitology Research, 101(3):731-736.

DOI: https://doi.org/10.1007/s00436-007-0537-4 


\title{
Comparative copro-diagnosis of Echinococcus multilocularis in experimentally infected foxes
}

\author{
M. N. S. Al-Sabi' • C. M. O. Kapel • P. Deplazes • \\ A. Mathis
}

Received: 7 March 2007 / Accepted: 11 April 2007 / Published online: 29 April 2007

(C) Springer-Verlag 2007

\begin{abstract}
Faecal samples from 15 foxes experimentally infected with Echinococcus multilocularis were examined until 90 days post-infection (dpi) by microscopical identification of eggs isolated by flotation/sieving, by coproantigenenzyme-linked immunosorbent assay (cELISA), by polymerase chain reaction (PCR) on DNA, respectively, isolated directly from the faecal samples (copro-DNA PCR) and from the eggs obtained by the flotation/sieving procedure (egg-DNA PCR). Based on egg counts, three periods of the infection were defined: pre-patent (2-29 dpi), high patent (30-70 dpi) and low patent periods (71-90 dpi). Whereas all methods were highly sensitive with samples from the high patent period, cELISA was the most sensitive to detect pre-patent infections (63\%). Samples from the low patent infections were positive in $77 \%$ by microscopy and in $80 \%$ by eggDNA PCR, being significantly more sensitive than cELISA and copro-DNA PCR. The isolation of eggs from the faecal material proved to be more sensitive by the flotation/sieving procedure as compared to the classical concentration McMaster technique.
\end{abstract}

M. N. S. Al-Sabi'

Danish Centre for Experimental Parasitology, Faculty of Life

Science, Copenhagen University,

Dyrlaegevej 100,

1870 Frederiksberg, Denmark

C. M. O. Kapel

Institute of Zoology, Department of Ecology, Faculty of Life

Science, Copenhagen University,

Thorvaldsensvej 40,

1871 Frederiksberg, Denmark

P. Deplazes $\cdot$ A. Mathis $(\bowtie)$

Institute of Parasitology, University of Zurich,

Winterthurerstrasse 266A,

CH-8057 Zurich, Switzerland

e-mail: alexander.mathis@access.unizh.ch

\section{Introduction}

The distinct increase in fox populations in central Europe, especially in densely populated urban areas, raised concerns about an increased risk of humans for contracting alveolar echinococcosis, which is caused by the larval stage of the fox tapeworm Echinococcus multilocularis (Deplazes et al. 2004). Indeed, a recent retrospective study documented such an increase in Switzerland (Schweiger et al. 2007). Humans contract the infection by ingesting worm eggs, which are excreted in faeces of the definitive hosts (mainly foxes, but also dogs). To estimate the potential risk of human infection or to assess the effect of potential control measures, reliable tools are required to diagnose the infection in definitive hosts. As eggs of E. multilocularis cannot be differentiated morphologically from those of other taeniid worms, alternative methods are needed. Immunological tests to detect antigens in faecal samples (coproantigen-enzyme-linked immunosorbent assays [cELISAs]) have been developed by several groups (reviewed by Deplazes et al. 2003; Machnicka et al. 2003). These tests have good sensitivities $(>90 \%)$ with samples from animals harbouring moderate to high worm burdens; their specificities range from 70-99\% (reviewed by Deplazes et al. 2003). As these tests have a relatively low positive predictive value in populations with low prevalences (Eckert 2003), positive cELISA results may require confirmation by the more laborious polymerase chain reaction (PCR). Detection by PCR may be performed on DNA directly isolated from faecal material ('copro-DNA'), which might contain PCR-inhibitory substances (Bretagne et al. 1993; Dinkel et al. 1998) or on DNA from tapeworm eggs isolated from the faecal material ('egg-DNA'; Mathis et al. 1996).

The present work aimed at comparing different diagnostic methods (microscopy, cELISA, PCR) to detect the 
presence of E. multilocularis in experimentally infected foxes 2 to 90 days post-infection (dpi). A new quantitative method for isolation of faecal eggs was evaluated (sieveMcMaster technique), and PCR was done on 'copro-DNA' and 'egg-DNA'. Special emphasis was placed on diagnostic sensitivity in the pre- and late patency where parasite material is less abundant.

\section{Materials and methods}

\section{Origin of samples}

Faecal droppings from originally 15 red foxes (Vulpes vulpes) experimentally infected with E. multilocularis (Kapel et al. 2006) were collected daily 2-90 dpi from the bottom of the cages and were, due to bio-safety precautions, stored at $-80^{\circ} \mathrm{C}$ for at least 3 days before any processing. The worm recovery (mean of five foxes) was 16,592 (range 11,732-19,700) 35 dpi, 331 (range 55-720) 63 dpi and 134 (range 10-419) 90 dpi as determined from five animals necropsied per time point (Kapel et al. 2006).

\section{Coproantigen-ELISA}

Detection of E. multilocularis coproantigens was performed according to Deplazes et al. (1999). Briefly, each faecal sample $(2 \mathrm{~g})$ was mixed at a ratio of 1:4 $(w / v)$ with buffer (phosphate-buffered saline containing $0.04 \% \mathrm{NaN}_{3}, 0.05 \%$ bovine haemoglobin [Fluka, Buchs, Switzerland] and 0.3\% Tween-20). After centrifugation at $3,000 \times g$ for $10 \mathrm{~min}$ at room temperature, the supernatant was used for ELISA. The cut-off value $(0.107)$ was calculated as the mean $A_{405}$ adsorbance value plus 3 standard deviations of readings done on faecal samples from ten animals 2 and 5 dpi.

\section{Isolation of faecal eggs}

The isolation of E. multilocularis eggs, conducted on the pellet resulting from the above coproantigen isolation, was done according to Mathis et al. (1996). Briefly, eggs were isolated by a combination of flotation in zinc chloride solution followed by sequential sieving through nylon nets with mesh sizes of 31 and $20 \mu \mathrm{m}$, respectively, as indicated by the supplier (Scrynel, Lanz-Anliker, Rohrbach, Switzerland). The fractions retained in the $20-\mu \mathrm{m}$ sieve containing the eggs were rinsed out from the inverted sieves into 10-ml flat-sided tissue culture tubes (Nunc, Roskilde, Denmark) and counted using an inverted microscope. Samples with more than 100 eggs were centrifuged at $1,000 \mathrm{rpm}$ for $5 \mathrm{~min}$, half of the sediment was transferred into a $15 \mathrm{ml}$ centrifuge tube and zinc chloride solution (specific gravity 1.45) was added to a final volume of $2 \mathrm{ml}$. After a gentle homogenisation, a $0.3-\mathrm{ml}$ aliquot of the egg suspension in zinc chloride was transferred into a McMaster slide (sieveMcMaster technique), and the number of eggs per gram (epg) was calculated according to the standard McMaster egg counting equation (Roepstorff and Nansen 1998).

\section{DNA isolation}

DNA isolation from concentrated eggs was performed according to Stefanic et al. (2004) using a commercial kit (Qiamp DNA mini kit, Qiagen, Hilden, Germany) and performing two final washing steps of the DNA binding column instead of one as suggested by the manufacturer. DNA was eluted in $100 \mu \mathrm{l}$ of $10 \mathrm{mM}$ TRIS-HCl, pH 8.3 and stored at $-20^{\circ} \mathrm{C}$ until use.

For DNA isolation directly from faecal droppings, $2 \mathrm{~g}$ of faecal material was placed in a 50-ml tube containing $2 \mathrm{ml}$ of double distilled water. After homogenisation and centrifugation at 2,000 $\mathrm{rpm}$ for $2 \mathrm{~min}$ at room temperature, alkaline lyses and neutralisation were done as previously described (Mathis et al. 1996) but with ten times the volumes of all solutions. After neutralisation, $14 \mathrm{ml}$ of buffer ASL (Qiamp DNA stool mini kit, Qiagen) were added, the samples were vortexed for $1 \mathrm{~min}$, centrifuged at $2000 \times \mathrm{g}$ for $2 \mathrm{~min}$ and $1.6 \mathrm{ml}$ of the supernatants were transferred into 2-ml microcentrifuge tubes. DNA was then isolated according to the protocol of the manufacturer with two modifications: (1) incubation with proteinase $\mathrm{K}$ was done at $56^{\circ} \mathrm{C}$ for $60 \mathrm{~min}$ and (2) the washing steps with both washing buffers were repeated once with $300 \mu \mathrm{l}$ instead of a single washing with $500 \mu$ l. DNA was eluted and stored as described above.

\section{PCR and sequencing}

Specific E. multilocularis DNA was detected by a modified PCR (Stieger et al. 2002) with the primer pair EM-H15 (5'-CCA TAT TAC AAC AAT ATT CCT ATC-3') and EM-H17 (5'-GTG AGT GAT TCT TGT TAG GGG AAG-3'), which amplifies a product of 200 bp from the E. multilocularis mitochondrial $12 \mathrm{~S}$ rRNA gene. Each sample was tested in triplicate, one with $25-\mu 1$ sample solution, the second with $2 \mu \mathrm{l}$ and the third using $2 \mu \mathrm{l}$ spiked with $1 \mu \mathrm{l}\left(10^{5}\right.$ copies $)$ of a cloned, size-modified control target that was created using composite primers (Celi et al. 1993). This control target, which detects amplification inhibition, yields an amplicon of $400 \mathrm{bp}$ upon amplification, which is easily discriminated from the E. multilocularis-specific product after gel electrophoresis. In each run, one negative control without DNA and one positive control (control plasmid DNA) were included. Amplicons were detected after electrophoresis of $15 \mu \mathrm{l}$ of PCR mixtures in $1.5 \%$ agarose gel and stained with 
ethidium bromide $(0.8 \mu \mathrm{g} / \mathrm{ml})$. The specimens, which lacked the internal control band of $400 \mathrm{bp}$, were considered as inconclusive and were re-tested in reactions containing bovine serum albumin $(1 \mu \mathrm{g} / \mu \mathrm{l})$. PCR with DNA isolated from eggs concentrated by sieving is referred to as "eggDNA PCR". Likewise, PCR with DNA isolated directly from faeces is referred to as "copro-DNA PCR". DNA sequencing was performed directly on amplicons by a private company (Microsynth, Balgach, Switzerland).

\section{Statistics}

Ninety-five percent confidence intervals were calculated on the basis of binomial distributions (Rozsa et al. 2000). Data were analysed using SPSS (version 10.0.1, 1999). Differences in sensitivity between the different tests were compared by the $2 \times 2$ contingency tables using the Fischer's exact test.

\section{Results}

The results of the microscopical egg detection, cELISA, egg-DNA PCR and copro-DNA PCR are summarised in Table 1. In addition, Fig. 1 presents the results of the different tests over the course of the infections.

\section{Microscopy of sieved samples}

Based on the egg counts, three periods of the infection were defined: pre-patent (2-29 dpi), high patent (30-70 dpi) and low patent periods (71-90 dpi). Eggs were identified in all samples $(n=12)$ from the high patent period, with the highest egg excretion between 33-39 dpi (max. 8,874 epg
$39 \mathrm{dpi})$. In the low patent period with average epg counts of 17 (range $0.5-225$ ), 7 of 30 samples were negative (sensitivity $77 \%$, Table 1). For comparative purposes, the egg floatation and sieving method (Mathis et al. 1996) and, if more than 100 eggs were detected, the sieve-McMaster (s-McMaster) technique were applied to aliquots of samples from the high and the low patent periods, respectively, for which the results obtained with the routinely performed concentrated McMaster (c-McMaster) technique were available (Kapel et al. 2006). Hence, from 19 faecal samples from the low patent period collected at $81,85,89$ and $90 \mathrm{dpi}$, only $1(5 \%)$ was positive with the c-McMaster technique, whereas eggs were detected in 17 samples $(89 \%)$ with the egg floatation and sieving method. Three of these positive samples had more than $20 \mathrm{epg}$, which is considered the cut-off diagnostic threshold of the c-McMaster technique (Roepstorff and Nansen 1998). Further, comparing the results obtained with aliquots of 17 samples from the high patent period, the s-McMaster method yielded 32\% higher egg counts as compared to the c-McMaster technique (not shown).

\section{Coproantigen-ELISA}

The ELISA optical density values of the samples from the beginning of pre-patency (6-10 dpi) were below cut-off, except for one sample at 10 dpi. During the second part of pre-patency (11-29 dpi), all samples were positive, and cELISA was the most sensitive method with samples from the pre-patent period compared to the three other methods. Five of the six samples investigated from the high patent period (30-70 dpi) were positive. In the following, low patent period (71-90 dpi), sensitivity was $40 \%$ for the 30

Table 1 Detection of Echinococcus multilocularis eggs, coproantigens and DNA in faecal material from experimentally infected foxes

\begin{tabular}{|c|c|c|c|c|c|c|c|c|}
\hline \multirow[t]{3}{*}{ Unit of detection } & \multicolumn{2}{|c|}{ Microscopy $^{a}$} & \multicolumn{2}{|l|}{ c-ELISA } & \multicolumn{2}{|c|}{ Egg-DNA PCR } & \multicolumn{2}{|c|}{ Copro-DNA PCR } \\
\hline & \multicolumn{2}{|l|}{ Eggs } & \multicolumn{2}{|l|}{ Antigens } & \multicolumn{2}{|c|}{ DNA from egg isolation } & \multicolumn{2}{|c|}{$\begin{array}{l}\text { DNA from worms and } \\
\text { eggs }\end{array}$} \\
\hline & $\begin{array}{l}\text { No. pos./ } \\
N\end{array}$ & $\%, \mathrm{CI}$ & $\begin{array}{l}\text { No. pos./ } \\
\mathrm{N}\end{array}$ & $\%, \mathrm{CI}$ & $\begin{array}{l}\text { No. pos./ } \\
N\end{array}$ & $\%, \mathrm{CI}$ & $\begin{array}{l}\text { No. pos./ } \\
N\end{array}$ & $\%, \mathrm{CI}$ \\
\hline $\begin{array}{l}\text { Pre-patent period, } 2- \\
29 \text { dpi }\end{array}$ & $0 / 27$ & $0 \%$ & $15 / 24$ & $\begin{array}{l}63 \% *, 41- \\
81\end{array}$ & $5 / 27$ & $19 \%, 6-38$ & $4 / 25$ & $16 \%, 5-36$ \\
\hline $\begin{array}{l}\text { High patent period, } 30- \\
70 \mathrm{dpi}\end{array}$ & $12 / 12$ & $\begin{array}{l}100 \%, 74- \\
100\end{array}$ & $5 / 6$ & $\begin{array}{l}83 \%, 36- \\
100\end{array}$ & $10 / 10$ & $\begin{array}{l}100 \%, 69- \\
100\end{array}$ & $6 / 6$ & $\begin{array}{l}100 \%, 54- \\
100\end{array}$ \\
\hline $\begin{array}{l}\text { Low patent period, } 71- \\
90 \text { dpi }\end{array}$ & $23 / 30$ & $77 \%, 58-90$ & $12 / 30$ & $\begin{array}{l}40 \%, 23- \\
59\end{array}$ & $24 / 30$ & $\begin{array}{l}80 \% * *, 61- \\
92\end{array}$ & $14 / 30$ & $47 \%, 28-66$ \\
\hline
\end{tabular}

The results of the different diagnostic tests are given as positive/total number of examined specimens (No. pos./N) and its percentage (\%). $C I 95 \%$ confidence interval. Statistical analysis (Fischer's exact test) was done to compare between coproantigen-ELISA and both types of PCR within the different patent periods

${ }^{a}$ Detection of eggs isolated by sieving (Mathis et al. 1996).

${ }^{*} p<0.01$, significantly different from both PCR tests

$* * p<0.01$, significantly different from cELISA and copro-DNA PCR 
Fig. 1 Compilation of the results of the four diagnostic techniques used in the study. Filled symbols indicate a positive result and open ones indicate a negative result. Error bars in the coproantigen-ELISA results refers to testing of multiple samples at a given time point while each circle represents one tested sample

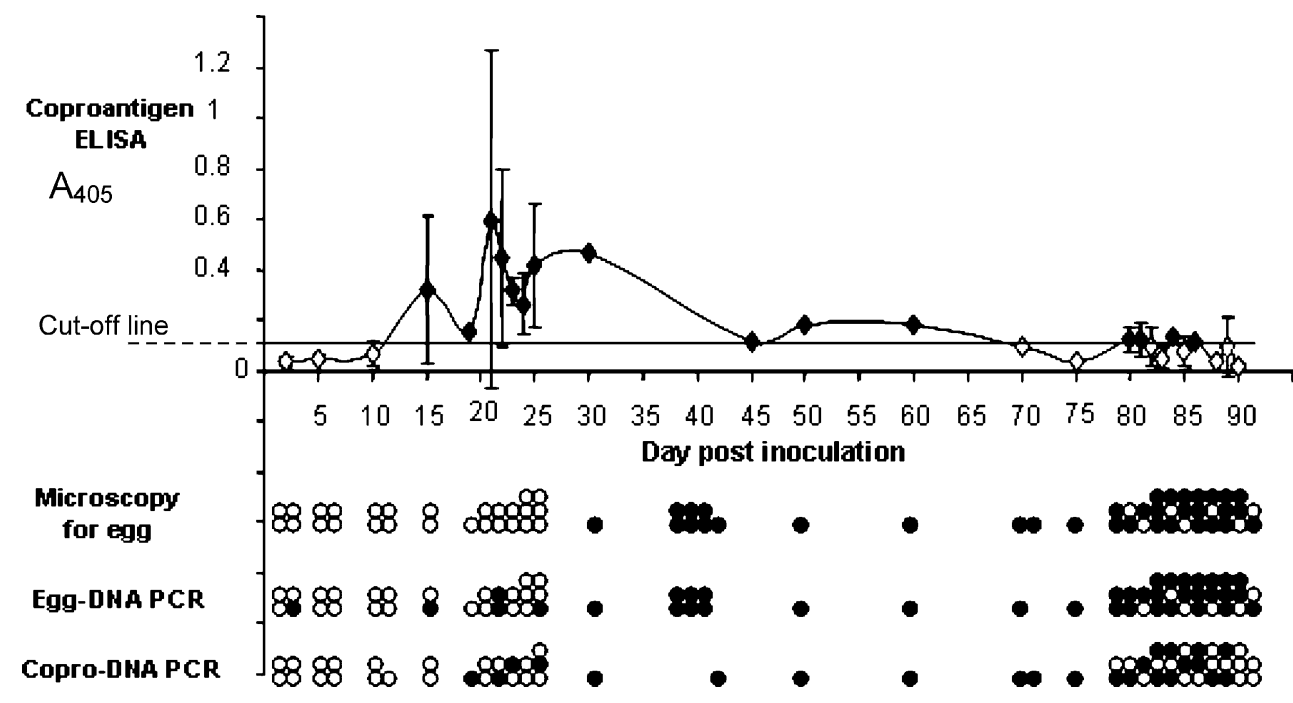

examined samples. The highest absorbance values were found in samples from the end of pre-patency and from the first day of the patent period (30 dpi, Fig. 1). During the low patent period, readings were close to the cut-off value.

PCR with DNA extracted from sieved material, egg-DNA PCR

Five of 27 samples from the pre-patent period were detected positive by egg-DNA PCR $(2,15,22,22$ and 25 dpi, Fig. 1). Sequencing of the sample from 2 dpi confirmed that the amplified product corresponded to the $E$. multilocularis target sequence. All tested samples $(n=10)$ from the high patent period (30-70 dpi) contained eggs and were found PCR positive, whereas DNA was successfully amplified from 24 of the 30 examined samples of the low patent period (sensitivity $80 \%$ ). From this later period, five of seven samples that did not contain eggs were found PCR negative, as was one sample with ten eggs.

PCR with DNA directly extracted from faeces, copro-DNA PCR

From the pre-patent period, 4 of 25 samples $(19,22,23$ and 25 dpi, Fig. 1) were found PCR positive after direct DNA extraction from faeces (sensitivity 16\%). All examined samples from the high patent period $(n=6)$ were coproDNA PCR positive, and sensitivity was $47 \%$ for the 30 samples from the low patent period. Negative PCR results were obtained with six out of seven samples, which did not contain eggs upon microscopical examination but also with ten samples in which eggs were detected. Sequencing of two samples ( 82 and 84 dpi) confirmed that the amplified product corresponded to the E. multilocularis target sequence. Moreover, nine samples that were negative by
copro-DNA PCR were positive by egg-DNA PCR, with egg counts ranging from 0 to 11 per $2 \mathrm{~g}$ of faecal sample.

A faecal sample collected 1 day before inoculation was examined and found negative by both the egg-DNA and the copro-DNA PCR techniques. Additionally, all four mock isolations with the egg-DNA and one with the copro-DNA extraction techniques yielded negative PCR results.

\section{Discussion}

The present study demonstrated that a modified McMaster technique including sieving improved the detection of $E$. multilocularis eggs at early patency as compared to the classical concentration McMaster technique. Theoretically, all eggs from a large faecal sample should be retained by the fine $20-\mu \mathrm{m}$ sieve, improving the subsequent visual detection in the flat sided 10-ml culture tube, while the c-McMaster technique, which is routinely being used in many labs, operates on sub-samples of the original $4 \mathrm{~g}$ of faeces. The present study confirms findings of Kapel et al. (2006) that foxes had highest egg excretions 33-39 dpi. However, in their study, eggs were not detected after 70 dpi (except for one sample $89 \mathrm{dpi}$ ), while the present study proves a very low but continuous excretion in three foxes up to $90 \mathrm{dpi}$.

The results of the cELISA confirm that antigen production most likely follows the metabolic activity of the worms, which increases just before patency, yielding high readings in the patent period and decreasing rapidly with decreasing worm burdens. It is commonly acknowledged that cELISA absorbance values are dependent on worm burdens (Deplazes et al. 1992; Yimam et al. 2002; Raoul et al. 2003; Reiterova et al. 2005). As the foxes examined in the present study were fed ad libitum, the concentrations of coproantigens in the gut contents were probably low 
compared to natural infections where food is scarcer. Consequently, the sensitivity of the assay may be reduced as previously suggested by Deplazes et al. (1992). Nonetheless, the coproantigen detection in the present study is in agreement with other experimental fox infections where the highest levels were found in the periods ranging from $18-20$ to $35-45$ dpi and after which it decreases (Nonaka et al. 1996; Deplazes et al. 1999). Using a commercial cELISA kit, Casulli et al. (2005) detected only 8 of 24 samples confirmed positive by copro-PCR, which may rely on high background reactions. During patency, Stieger et al. (2002) found $88 \%$ sensitivity of the cELISA as compared to egg-DNA PCR, but found also "false positive", which were ascribed either to crossreactions or to the detection of pre-patent infections. For the detection of natural infections, where most foxes harbor relatively few worms (Hofer et al. 2000), cELISA may underestimate the true prevalence.

The major obstacle facing copro-PCR tests is the presence of inhibitory substances, and several laborious attempts have been made to eliminate their presence in the DNA extracted from faecal material, including the isolation of worm eggs before DNA isolation (Bretagne et al. 1993; Mathis et al. 1996; Monnier et al. 1996; Dinkel et al. 1998). Commercial kits tailored for DNA isolation from specimens rich in PCR inhibitory substances (faeces and soil) are available, but pretreating the faecal samples to disrupt the taeniid egg's keratin layer remains essential. Further, these kits can only process approximately $0.2 \mathrm{~g}$ of faeces, which is not sufficient to detect low-grade taeniid infections. In this study, we applied a protocol for the initial processing of larger faecal samples $(2 \mathrm{~g})$, which due to capacity limitations of the DNA adsorbing matrix employed in this kit, does not yield more DNA than when starting with the standard $0.2 \mathrm{~g}$ but allows to enhance the chances of isolating DNA from rare sources. However, in low patent period, the sensitivity of PCR with samples from which DNA was obtained by copro-DNA isolation method was significantly lower than with samples from which DNA was isolated after egg enrichment methods (egg-DNA PCR; Table 1).

Inhibition occurred in some samples investigated with the copro-DNA PCR as was obvious from the faintness of the bands of the amplified internal control target. Nonetheless, the copro-DNA PCR was slightly more sensitive for detection of patent infections than the cELISA. The noticed increased sensitivity of the copro-DNA PCR at the low patent period compared to that of the pre-patent infection can be attributed to the presence of the eggs, which provides a pure source of DNA. Similarly, Dinkel et al. (1998) concluded that samples containing mature E. multilocularis eggs in faeces were more reliably detected by PCR than infections with immature worms. Hence, the copro-DNA PCR method has the potential to detect more patent infections if inhibition problems could be overcome (Mathis and Deplazes 2006).

Interestingly, PCR on sieved samples (designed to isolate eggs) in 5 out of 27 samples from the pre-patent period and in 2 samples not containing eggs from the low patent period had successfully amplified E. multilocularis DNA. Most likely, cells or tissue fragments from disintegrated worm segments were retained in the nylon nets. Although the strategy of egg-DNA PCR is not adequate to examine egg-free samples or samples containing immature E. multilocularis worms (Mathis et al. 1996; van der Giessen et al. 1999), previous copro-DNA PCR studies have reported the detection of E. multilocularis DNA in such samples (Bretagne et al. 1993; Dinkel et al. 1998; Yamasaki et al. 2002; Deplazes et al. 2003). Eggs in faecal samples may be overlooked or eggs can get disintegrated or miss-shaped due to storage or processing conditions. This implies that the egg-DNA PCR assay may be more sensitive for diagnosing patent infections than the microscopical detection of the eggs enriched by sieving.

Due to the different number of samples investigated from the various periods, no overall sensitivities can be given for the methods applied, and no single method was optimal for diagnosis throughout the duration of the infection. The surprisingly high sensitivity of microscopical detection of eggs after their enrichment by flotation/sieving combined with their identification by molecular means (PCR) implies that this strategy is to be followed to detect patent infections, whereas cELISA is the most sensitive method for diagnosing infections in the pre-patent phase.

Acknowledgements The Danish Veterinary and Agricultural Research Council and the Danish National Research Foundation are thanked for substantial financial support to the present study. The competent staffs at the research facility "Lindholm" of the Danish Institute for Food and Veterinary Research and at the Institute of Parasitology (University of Zurich) are acknowledged for hard work, flexibility and logistical support.

\section{References}

Bretagne S, Guillou JP, Morand M, Houin R (1993) Detection of Echinococcus multilocularis DNA in fox faeces using DNA amplification. Parasitology 106:193-199

Casulli A, Manfredi MT, La Rosa G, Di Cerbo AR, Dinkel A, Romig T, Deplazes P, Genchi C, Pozio E (2005) Echinococcus multilocularis in red foxes (Vulpes vulpes) of the Italian Alpine region: is there a focus of autochthonous transmission? Int J Parasitol 35:1079-1083

Celi FS, Zenilman ME, Shuldiner AR (1993) A rapid and versatile method to synthesize internal standards for competitive PCR. Nucleic Acids Res 21:1047

Deplazes P, Gottstein B, Eckert J, Jenkins DJ, Ewald D, JimenezPalacios S (1992) Detection of Echinococcus coproantigens by 
enzyme-linked-immunosorbent-assay in dogs, dingoes and foxes. Parasitol Res 78:303-308

Deplazes P, Alther P, Tanner I, Thompson RCA, Eckert J (1999) Echinococcus multilocularis coproantigen detection by enzymelinked immunosorbent assay in fox, dog, and cat populations. J Parasitol 85:115-121

Deplazes P, Dinkel A, Mathis A (2003) Molecular tools for studies on the transmission biology of Echinococcus multilocularis. Parasitology 127:S53-S61

Deplazes P, Hegglin D, Gloor S, Romig T (2004) Wilderness in the city: the urbanization of Echinococcus multilocularis. Trends Parasitol 20:77-84

Dinkel A, von Nickisch-Rosenegk M, Bilger B, Merli M, Lucius R, Romig T (1998) Detection of Echinococcus multilocularis in the definitive host: coprodiagnosis by PCR as an alternative to necropsy. J Clin Microbiol 36:1871-1876

Eckert J (2003) Predictive values and quality control of techniques for the diagnosis of Echinococcus multilocularis in definitive hosts. Acta Trop 85:157-163

Hofer S, Gloor S, Muller U, Mathis A, Hegglin D, Deplazes P (2000) High prevalence of Echinococcus multilocularis in urban red foxes (Vulpes vulpes) and voles (Arvicola terrestris) in the city of Zurich, Switzerland. Parasitology 120:135-142

Kapel CMO, Torgerson PR, Thompson RCA, Deplazes P (2006) Reproductive potential of Echinococcus multilocularis in experimentally infected foxes, dogs, raccoon dogs and cats. Int $\mathrm{J}$ Parasitol 36:79-86

Machnicka B, Dziemian E, Rocki B, Kolodziej-Sobocinska M (2003) Detection of Echinococcus multilocularis antigens in faeces by ELISA. Parasitol Res 91:491-496

Mathis A, Deplazes P (2006) Copro-DNA tests for diagnosis of animal taeniid cestodes. Parasitol Int 55:S87-S90

Mathis A, Deplazes P, Eckert J (1996) An improved test system for PCR-based specific detection of Echinococcus multilocularis eggs. J Helminthol 70:219-222

Monnier P, Cliquet F, Aubert M, Bretagne S (1996) Improvement of a polymerase chain reaction assay for the detection of Echinococcus multilocularis DNA in faecal samples of foxes. Vet Parasitol 67:185-195

Nonaka N, Iida M, Yagi K, Ito T, Ooi HK, Oku Y, Kamiya M (1996) Time course of coproantigen excretion in Echinococcus multi- locularis infections in foxes and an alternative definitive host, golden hamsters. Int J Parasitol 26:1271-1278

Raoul F, Michelat D, Ordinaire M, Decote Y, Aubert M, Delattre P, Deplazes P, Giraudoux P (2003) Echinococcus multilocularis: secondary poisoning of fox population during a vole outbreak reduces environmental contamination in a high endemicity area. Int J Parasitol 33:945-954

Reiterova K, Miterpakova M, Turckova U, Antolova D, Dubinsky P (2005) Field evaluation of an intravital diagnostic test of Echinococcus multilocularis infection in red foxes. Vet Parasitol 128:65-71

Roepstorff A, Nansen P (1998) The epidemiology, diagnosis and control of helminth parasites of swine. FAO Animal Health Manual 3, Food and Agriculture Organization of the United Nations, Rome, Italy

Rozsa L, Reiczigel J, Majoros G (2000) Quantifying parasites in samples of hosts. J Parasitol 82:228-232

Schweiger A, Ammann RW, Candinas D, Clavien P-A, Eckert J, Gottstein B, Halkic N, Muellhaupt B, Mareike-Prinz B, Reichen J, Tarr PE, Torgerson PR, Deplazes P (2007) Emerging alveolar echinococcosis in Swiss residents in the wake of an increase in fox population density. Emerg Inf Dis (in press)

Stefanic S, Shaikenov BS, Deplazes P, Dinkel A, Torgerson PR, Mathis A (2004) Polymerase chain reaction for detection of patent infections of Echinococcus granulosus ("sheep strain") in naturally infected dogs. Parasitol Res 92:347-351

Stieger C, Hegglin D, Schwarzenbach G, Mathis A, Deplazes P (2002) Spatial and temporal aspects of urban transmission of Echinococcus multilocularis. Parasitology 124:631-640

van der Giessen JWB, Rombout YB, Franchimont JH, Limper LP, Homan WL (1999) Detection of Echinococcus multilocularis in foxes in the Netherlands. Vet Parasitol 82:49-57

Yamasaki H, Nakao M, Sako Y, Nakaya K, Sato MO, Mamuti W, Okamoto M, Ito A (2002) DNA differential diagnosis of human taeniid cestodes by base excision sequence scanning thyminebase reader analysis with mitochondrial genes. J Clin Microbiol 40:3818-3821

Yimam AE, Nonaka N, Oku Y, Kamiya M (2002) Prevalence and intensity of Echinococcus multilocularis in red foxes (Vulpes vulpes schrencki) and raccoon dogs (Nyctereutes procyonoides albus) in Otaru City, Hokkaido, Japan. Jpn J Vet Res 49:287-296 